\title{
BM] Global Health Three-way partnerships fuel primary health care success
}

To cite: Ghaffar A, Swaminathan S, Gupta A, et al. Three-way partnerships fuel primary health care success. BMJ Glob Health 2019;4:e001579. doi:10.1136/ bmjgh-2019-001579

Handling editor Seye Abimbola

Received 25 March 2019 Accepted 30 March 2019

Check for updates

(c) Author(s) (or their employer(s)) 2019. Re-use permitted under CC BY-NC. No commercial re-use. See rights and permissions. Published by BMJ.

${ }^{1}$ Alliance for Health Policy and Systems Research, World Health Organization, Geneve, Switzerland

${ }^{2}$ Office of Deuputy Director General for Programmes and Corporate Operations, Organisation mondiale de la Sante, Geneve, Switzerland ${ }^{3}$ Gavi, the Vaccine Alliance, Geneva, Switzerland ${ }^{4}$ Programme Division, Health Section, United Nations Children's Fund, New York City, New York, USA

${ }^{5}$ Family and Population Health, Johns Hopkins University Bloomberg School of Public Health, Baltimore, Maryland, USA

Correspondence to

Dr Abdul Ghaffar;

ghaffara@who.int
In the summer of 1970, Drs Raj and Mabelle Arole finished their graduate public health studies in the USA and arrived in rural Maharashtra, India, searching for a community where they could make a difference. They had a primary health care (PHC) blueprint for community health improvement in rural India that had everything anyone could ask for. They envisioned a small hospital surrounded by subcentres, teams of nurses and paramedical workers, sanitation work, integration of prevention and cure and community participation. A community meeting with villagers in a potential site seemed like a textbook beginning. They described their first such meeting in Osmanabad district. ${ }^{1}$ The village leader had ordered 40 village heads to the meeting. None of them spoke; they nodded assent to all of the leader's suggestions. Dr Arole suggested that they should hear from the villagers. The host found the suggestion perplexing, saying 'I just have to give the order and the people will follow'.

If they had merely been interested in building a medical clinic to provide primary medical care, then an alliance with a powerful local politician would have been supremely attractive. That power would have helped to secure facilities and patronage that propel success in organising medical care. However, the Aroles dreamed of much more than just delivering primary care, and they clung to their vision. They moved to a neighbouring district and persisted in building the community partnerships that became the foundation of their half century of success in Jamkhed. ${ }^{2}$ The slow path to create those partnerships started with building trust by listening and being willing to adapt their original blueprint. As it turned out, the highest priority of the people of Jamkhed was just to secure better access to medical care, and so the doctors focused on clinical services first, even though that implied that their community health promotion agenda would have to wait.
An opening arose. The people and their local politicians faced extreme drought in the early 1970 s. Water security soon became a crisis and the Aroles convened collective action to drill wells. The first community groups that the Aroles were able to start in Jamkhed were not health groups; they were farmer's clubs to discuss best practices in agriculture. Later came women's groups called Mahila Vikas Mandal. The Aroles were slow and deliberate, always being sure to include local politicians and credit them. Once the farmer's clubs and women's groups were established, they were gradually transformed to include community participation in planning for health.

In the years prior to the 1978 Alma-Ata Conference on Primary Health Care, the case study of the achievements in Jamkhed figured influentially in a book compiled by the WHO and Christian Medical Commission. ${ }^{3}$ The elements of primary health care listed in Article VII of the Alma-Ata Declaration stress multisectorality and 'maximum community participation in planning, operation, and control of primary health care' because conference planners for Alma-Ata were familiar with these elements at work in places like Jamkhed, in rural Cuba and among the barefoot doctors of China. ${ }^{3}$ Both the Alma-Ata Declaration and the Astana Declaration affirm that individuals, families, communities and civil society participate in planning and doing the things that make their communities healthy. For 40 years, the core principle of primary health care has been the opposite of 'give the order and the people will follow'.

The most sustainable and effective partnerships are explicitly three-way partnerships involving grass roots citizens, local political leaders and technical health experts. ${ }^{4}$ When development is understood as an improvement in the capacity of people in places to improve all aspects of well-being, then it is easy to see why community participatory primary 
health care is a core strategy in achieving both health and non-health Sustainable Development Goals. ${ }^{5}$ The three-way partnership naturally sustains progress because the ordinary citizens of a community whose lives are most affected by the outcomes are at the table and because the political leaders who control local purse strings are put in touch with what can be an expression of local will. The presence of a technical expert who can bring data about the size, scope, determinants and evidence-based solutions is critical to bring 21st century breakthroughs into the hands of the people and their local political leaders who can best determine how to adapt them to context.

In this landscape, United Nations (UN) agencies and global Non-governmental organizations (NGOs) have a dual role in stewarding the world's response to global health threats while ensuring that communities around the world are able to execute their local vision for three-way partnerships like the vision the Aroles had for Jamkhed. Global institutions are best known for their work in shepherding institutions to solve global problems. ${ }^{6}$ Unicef, WHO, Gavi, the Vaccine Alliance and organisations like these have been leading efforts that support knowledge creation in the implementation science of community participatory primary health care and the three-way partnership. Over the last few years, the Alliance for Health Policy and Systems Research, Unicef and Gavi have been embedding research inside practice innovations. Programme managers simultaneously innovate new approaches at the district and programme level and systematically observe and document the reaction of the system. The research lens and the scope of innovation is widened to be deliberately multisectoral integrating livelihoods, environment, the private sector and civil society. Implementation research supported by UN agencies helps to develop new strategies to deploy community health workers. ${ }^{7}$ Unicef worked with partners in Africa and Asia to develop methods for district level practice improvement based on detecting bottlenecks and working with partners to reduce them. ${ }^{8}$ WHO headquarters and regional offices routinely offer technical support for member countries' efforts to build capacity in strengthening community-participatory health endeavours. Gavi's health system strengthening investments have been used to improve community partnerships as well.

As the Aroles learnt almost 50 years ago in Jamkhed, balanced and authentic three-way partnerships can be elusive. Political leaders and technical experts do not always value sharing control and power with citizens. Mistrust and suspicion occur when insufficient attention is paid to the human trust-building side. Project cycles emphasise lean budgets that focus on moving commodities into bodies and not on building local institutions. Three-way partnerships seldom happen without the intention of an enlightened champion who has persistence and patience and skill.

Given the obstacles to success, it is common to see shortcuts in community partnership building. There are countless interventions where a health agency bypasses the local governmental funding mechanisms to work directly with citizens bringing outside resources for a project that is overly reliant on external support. Top-down modalities where public health workers plan and execute health programme without citizen input are also common. These approaches may achieve success on their own terms. This style of community health has an important place during crises and emergencies. However, top-down public health cannot be a long-term success strategy. Shortcuts must not crowd out the necessary work of building three-way partnerships.

There is a curious parallel between the donor-recipient dichotomy and the provider-patient dichotomy. In both cases, there is a resource asymmetry where one party has items that could help the other. The asymmetry can create a power imbalance that could ultimately defeat the purpose of improved mutual well-being. While the recipient and the patient may appear to have less power, they bring an essential ingredient to the enterprise-they know best how to put the advice and assistance into their own life practice.

Conducting methodical implementation research that examined teachable and learnable collective action methods in communities was how Elinor Ostrom won the 2009 Nobel Prize in Economics. ${ }^{9}$ Her work helped many others realise that community change requires authentic partnerships, and this insight illuminates the current supplement. The prioritised research areas in this supplement center around: (1) quality, safety and performance management; (2) PHC policies and governance; (3) organisation and models of care; and (4) PHC financing. All of these areas benefit from better understanding of the three-way partnerships between experts, politicians and people. In the area of quality and patient safety, there are exciting innovations in community-controlled scorecards that help remind clinicians that they are accountable. This same type of bottom-up accountability is being applied to measuring whether district level public health officials are doing their job in achieving essential public health functions. Ultimately, the reforms that will deliver and finance PHC will require a public health workforce with skills to build political support from both politicians and the people they serve.

Solidarity and partnership between those who bring technical knowledge and resources and those who bring contextual knowledge and own the problems being solved is the key to three-way partnerships at the heart of community-based multisectoral primary health care. In a balanced partnership, the partners are all honoured for bringing their specialty to bear to address a shared problem. That is why the skill set necessary for creating the platforms that support these partnerships is so critical.

Ultimately in the Jamkhed Project, like so many successful projects, a critical ingredient was an unwavering commitment by the leadership to settle for nothing less than a full three-way partnership. The shortcut of a local politician's executive order was not an option. Combined with perseverance and commitment, is a set of researchable and teachable techniques in listening 
to people, ensuring inclusion and sensitivity to local cultures and populations. There is an art to this facilitation that is similar to but far less celebrated than the art of the clinical healer. In the coming years, as we commit to implementing community-based primary health care strategies to implement the Astana Declaration, we will need research and capacity building in sustaining community three-way partnerships.

Contributors All authors contributed equally and have read the final submission.

Funding The authors have not declared a specific grant for this research from any funding agency in the public, commercial or not-for-profit sectors.

Competing interests None declared.

Patient consent for publication Not required.

Provenance and peer review Not commissioned; internally peer reviewed.

Data availability statement There is no additional data available.

Open access This is an open access article distributed in accordance with the Creative Commons Attribution Non Commercial (CC BY-NC 4.0) license, which permits others to distribute, remix, adapt, build upon this work non-commercially, and license their derivative works on different terms, provided the original work is properly cited, appropriate credit is given, any changes made indicated, and the use is non-commercial. See: http://creativecommons.org/licenses/by-nc/4.0/.

\section{REFERENCES}

1. Arole M, Arole R. Jamkhed. New York: MacMillan, 1994.

2. Black RE, Taylor CE, Arole S, et al. Comprehensive review of the evidence regarding the effectiveness of community-based primary health care in improving maternal, neonatal and child health: 8 . summary and recommendations of the expert panel. $J$ Glob Health $2017 ; 7$

3. Newell K. Health by the people. Geneva: WHO, 1975.

4. Taylor CE, Taylor-Ide D, Just A. Lasting change: when communities own their own futures. Baltimore: Johns Hopkins University Press, 2002.

5. Bhutta ZA. Community-based primary health care: a core strategy for achieving sustainable development Goals for health. J Glob Health $2017 ; 7$.

6. Smith RD. Global public goods and health. Bull World Health Organ 2003;81.

7. Pfaffmann Zambruni J, Rasanathan K, Hipgrave D, et al. Community health systems: allowing community health workers to emerge from the shadows. Lancet Glob Health 2017;5:e866-7.

8. Rupani MP, Gaonkar NT, Bhatt GS. Bottleneck analysis and strategic planning using Tanahashi model for childhood diarrhea management in Gujarat, Western India. Eval Program Plann 2016;58:82-7.

9. Earl PE, Potts J. A Nobel Prize for governance and institutions: Oliver Williamson and Elinor Ostrom. Review of Political Economy $2011 ; 23: 1-24$. 